Please do not remove this page

RMIT

UNIVERSITY

\title{
Issues in sustainable tourism
}

Clulow, Val; Walters, Gabrielle

https://researchrepository.rmit.edu.au/esploro/outputs/9921859655301341/filesAndLinks?institution=61RMIT_INST\&index=null

Clulow, V., \& Walters, G. (2013). Issues in sustainable tourism. The International Journal of Sustainability Policy and Practice, 8(3), 11-19.

https://researchrepository.rmit.edu.au/discovery/fulldisplay/alma9921859655301341/61RMIT_INST:Resea rchRepository

Document Version: Published Version

Repository homepage: https://researchrepository.rmit.edu.au

(c) 2013 (individual papers), the author(s)

Downloaded On 2023/04/26 16:00:40 +1000

Please do not remove this page 
Thank you for downloading this document from the RMIT Research Repository.

The RMIT Research Repository is an open access database showcasing the research outputs of RMIT University researchers.

RMIT Research Repository: http://researchbank.rmit.edu.au/

\section{Citation:}

Clulow, V and Walters, G 2013, 'Issues in sustainable tourism', The International Journal of Sustainability Policy and Practice, vol. 8, no. 3, pp. 11-19.

See this record in the RMIT Research Repository at:

http://researchbank.rmit.edu.au/view/rmit:22831

Version: Accepted Manuscript

Copyright Statement: (c) 2013 (individual papers), the author(s)

Link to Published Version:

http://ijspp.cgpublisher.com/product/pub.274/prod.37 


\title{
Issues in Sustainable Tourism
}

\author{
Valerie Clulow, RMIT University, Australia \\ Gabrielle Walters, University of Queensland, Australia
}

\begin{abstract}
Tourism offers an opportunity for major development as a linchpin industry in the structural adjustment necessary to transition to a lower carbon economy in some regions. Drivers for the development of a tourism industry can be primarily economic sustainability without due reference to environmental sustainability. Several issues are emerging including the need for regulation. There is a view in the literature that challenges the potential for ongoing self-regulation by the tourism industry — via instruments such as company-led environmental management systems and social responsibility initiatives and voluntary codes of conduct set up by companies or by association of companies. The basis for this view is that self-regulation is by definition voluntary and that industry's behaviour can often revert to short-term self-interest at the cost of following environmental standards. The second issue is around the concept that "environmentally friendly tourism" is a niche market and not the main game, that it brings with it higher costs though a lower environmental footprint, and that there is a tension between tourism development and sustainable tourism. The third issue is a more positive, optimistic view that there are potentially market segments that are environmentally friendly as well as providing higher economic returns. These issues are explored via a theoretical focus.
\end{abstract}

Keywords: Sustainable Tourism, Economically Sustainable Tourism, Environmentally Sustainable Tourism

\section{Introduction}

7 The tourism industry is a particularly interesting case example on the question of sustainability at this time in history. The focus of much ecotourism activity is naturebased. However, pressure has increased on this industry in recent years to become an economic driver of structural adjustment, facilitate growth and become an alternative economically sustainable contributor (Henderson, 2006). The timing of these initiatives coincides with greater awareness and media coverage about climate change, global warming and ecologically sustainable approaches to development. The question of the degree of urgency for regulation of tourism generally, to moderate the seemingly divergent imperatives, has been mooted in the literature for well over a decade (Bramwell, 1998; Hunter and Green, 1995; Williams and Montanari, 1999). Indeed many years ago, Budowski (1976) proposed that “...three different relationships can exist between those promoting tourism and those advocating conservation of Nature” (p. 27). These are:

1) tourism development and nature conservation are in conflict

2) there can be sustainable tourism and economic development

3) there can be a state of 'symbiosis' between sustainable ecotourism and social economic development

Romeril (1985) recognised that,

"There is little doubt that a widespread awareness of the interrelatedness of tourism and environmental conservation does now exist but a feeling remains that so much is an exercise in dialectics” (p. 216).

More recently, the issue is being explored further from different perspectives such as, the role of government planning (Bramwell and Lane, 2010), the potential of voluntary agreements and self-regulation (Ayuso, 2007), the value of tour operator-initiated codes of conduct (Parsons

The International Journal of Sustainability Policy and Practice

Volume 8, 2013, onsustainability.com, ISSN: 2325-1166

(C) Common Ground, Valerie Clulow and Gabrielle Walters, All Rights Reserved

Permissions: cg-support@commongroundpublishing.com 
and Woods-Ballard, 2003) and the need to balance any move towards greater regulation with care to avoid stifling innovation (Bramwell and Lane, 2010).

As with many developments in business thinking in the modern age, the big questions are somewhat fraught with the evolution of the concept of the validity of different stakeholder perspectives on the same issue (Freeman and Evan, 1990), the dramatic changes and emerging political positions of many countries on ecotourism (Duffy, 2006) and the challenges to businesses to remain sustainable that are becoming more apparent as a result of climate change (Garnaut, 2011).

There are three key issues addressed in this paper. These are: the primary question of the need for greater regulation of the tourism, the tension between tourism development and sustainable tourism and the potential for co-existence of environmentally friendly ecotourism along with economic returns.

\section{Thematic Focus and Approach}

The three key issues identified in the literature pertaining to tourism development will inform the structure of the paper and related literature will be reviewed. The approach to developing a reflective profile of the three issues with a global perspective, will be to discuss indicative selected case studies, from different continents of the world, that inform and illustrate the challenges facing the tourism industry worldwide and the potential for moving forward sustainably. While cases are not the basis for generalisability, they are useful in the development of insights into complex scenarios.

\section{Literature Review}

\section{Regulation and the Tourism Industry}

As mentioned the question of the need for regulation or not, has been raised in the literature for over a decade. Most recently, an interesting study by Parsons and Ballard (2003), found that the involvement of tour operators in the UK, in self-regulatory voluntary activity was more effective, than their reference to guidelines produced by the UK government, for the whale-watching tours in West Scotland. The study indicated that of the small sample (30 operators) $86 \%$ did refer to a code of conduct, with $43 \%$ referring to the code produced by their own association. Only $27 \%$ of the sample were even aware of the government guidelines (Parsons and Ballard, 2003, p172). So while the locally produced codes were most used as a point of reference, more robust investigation would inform why the Government codes were not well known. The promotion and dissemination of such material may be an issue, rather than the perceived value of the content per se.

The promotion and tangible evidence aspects of such guidelines was a relevant feature of a study by Ayuso (2007). This study provides an analysis of the extent of use by 30 hotel operators in Spain, of “...voluntary policy instruments most commonly applied by the hotel sector: codes of conduct, best environmental practices, ecolabels, environmental management systems (EMSs) and environmental performance indicators” (p.144). A key finding was the lack of awareness of existing codes, again indicating the importance of dissemination and ongoing, effective promotion and emphasis.

The study showed that,

“...formal certification systems such as ecolabels and EMSs appear to be the most effective instruments. At a conceptual level, ecolabels and EMSs are the tools with the broadest scope and the only ones that guarantee an improvement of the company's environmental (and sustainable) performance. At the practical level, the present research shows that, although both of these instruments involve higher costs and complexity than 
the other tools studied, they offer a wider range of tangible and intangible benefits” (p.144).

The issue of cost raised by Ayuso is seen as an advantage, where cost savings are reaped by hotel operators when they change routines, but upfront investment costs for options such as solar panels, were regarded as difficult in the short term. However, the relatively high costs associated with applying the different ecolabels (€1500 and €3500) for the first certification, and annual membership fees (€60 and €1000) were regarded as sending a good signal to clients about the hotel's attitude to the environment, but problematic as an additional cost that did not generate sales (p.151).

While the previous three decades or so in Australia and many other developed economies have seen a greater predisposition for deregulation in planning (Bramwell and Lane, 2010, p.2) it is true to say the growth of service industries really only ramped up through the 1970s. As Bramwell and Lane (2010) indicate, the global financial crisis has provided a stark reminder, that self-regulation has associated high risks. The Australian government not only stepped in to shore up the Australian economy during 2008-2010 but also announced (July 10, 2011) that a carbon tax will be introduced. However, the state of the economies of the world, while driving greater intervention and control in some quarters, may find the costs associated with greater regulatory interventions in others, prohibitive.

This central question for the tourism industry sometimes appears to be in juxtaposition to the political imperative to do more to safeguard the natural environment, amid myriad demands on stretched national budgets and political vulnerability.

\section{Tourism Development and Sustainable Tourism}

The concept of sustainable ecotourism is described by Klak (2007, p.1041 ) as “...simultaneously economically viable, positive for the host and visitor community, and contributes to environmental conservation...”. This balancing imperative is the challenge.

In very recent years, the paradoxical interplay has emerged, between the three aspects in that-

I. the ecotourism industry is being sought out to replace other unsustainable industries, such as long term oil production in the middle east and brown coal mining in Australia

II. the ecotourism industry is reliant on a rich, unspoiled natural environment

III. the greater the use of the natural environment for ecotourism promotion results in greater impact on that environment and its community.

Moeller, Dolnicar and Leisch, 2011) have undertaken a major survey of 1003 Australian domestic tourists, to explore the extent to which the current tourism market in Australia, has low environmental footprint tourism options while maintaining high tourist expenditure. They found that while "...tourist segments vary significantly in terms of their environmental impacts and vacation expenditure...” (p.155), two segments that represent $40 \%$ of the Australian tourism market, leave “...small environmental footprints while maintaining high expenditure...” (p.155).

So, while the perception of operators and tourists is that sustainable tourism choices are high cost and yield low returns, and require 'sacrifices' on the part of tourists (higher cost, walking not driving, time/energy to remove rubbish etc), this study indicates the potential for the development of marketing strategies and directions for industry development that can act in synergy with sustainable tourism principles.

\section{Research Design}

Taking a theoretical focus, recently published cases were sourced across countries from different continents, that demonstrate the cogency of the concerns facing the tourism industry. While this 
is a limited sample, the purpose of the paper is to provide a snapshot in time; a world overview of indicative cases that provide insights into the current view of the issues in question, namely that-

1) tourism development and nature conservation are in conflict

2) there can be sustainable tourism and economic development

3) there can be a state of 'symbiosis' between sustainable ecotourism and social economic development

and to critique and analyse these cases to ascertain the similarities and differences on these issues in very different world locations.

A search was undertaken of recently published articles using search terms such as sustainable tourism and regulation; tourism regulation; economically sustainable tourism; environmentally sustainable tourism. The following cases were selected on the basis that they provided a perspective on the issues that enables comparative analysis between cases across continents. The cases are summarised in Table 1.

Table 1: Cases that capture ecotourism issues

\begin{tabular}{|l|l|l|}
\hline Author(s & Article & Continent \\
\hline $\begin{array}{l}\text { Magole, Lefatshe I. and } \\
\text { Magole, Lapologang }\end{array}$ & $\begin{array}{l}\text { Revisiting Botswana's high-value, low-volume } \\
\text { tourism, Tourism Analysis, 16, 203-210, (2011). }\end{array}$ & Africa \\
\hline $\begin{array}{l}\text { Hall, Michael C. and } \\
\text { Saarinen, Jarkko }\end{array}$ & $\begin{array}{l}\text { Scandinavian Journal of Hospitality and Tourism, } \\
\text { Scandinavian Journal of Hospitality and Tourism, } \\
\text { 10(4)448-467, 2010. }\end{array}$ & Antarctica \\
\hline $\begin{array}{l}\text { Scherrer, Pascal., Smith, } \\
\text { Amanda J., Dowling, } \\
\text { Ross K. }\end{array}$ & $\begin{array}{l}\text { Visitor management practices and operational } \\
\text { sustainability: Expedition cruising in the Kimberley, } \\
\text { Australia, Tourism Management, 321218-1222, } \\
\text { (2011) }\end{array}$ & $\begin{array}{l}\text { Australia/ } \\
\text { Oceana }\end{array}$ \\
\hline Yamada, Naoko & $\begin{array}{l}\text { Why tour guiding is important for eco-tourism: } \\
\text { enhancing guiding quality with the eco-tourism } \\
\text { policy in Japan, Asia Pacific Journal of Tourism } \\
\text { Research, 16(2)139-152, (2011). }\end{array}$ & Eurasia \\
\hline Klak, Thomas & $\begin{array}{l}\text { Sustainable Ecotourism Development in Central } \\
\text { America and the Caribbean: Review of Debates } \\
\text { and Conceptual Reformulation, Geography } \\
\text { Compass 1/5, 1037-1057, 2007 }\end{array}$ & Americas \\
\hline
\end{tabular}

Each country's case will be presented in summary then a comparative analysis discussed and issues for future research provided.

\section{Analysis of Cases}

Botswana, Africa: In their recent article, Revisiting Botswana's high-value, low-volume tourism, Magole and Magole (2011) outline the tourism strategy of high-value and low-volume that has been adopted on a premise that this approach minimises “...negative environmental impacts on pristine wildlife areas while maximizing socioeconomic benefits” (p.203). They claim that this strategy maintains reliance on wealthy foreign ownership and repatriation of profits from Botswana, or enclave tourism, rather than building capacity that addresses social equity in the tourism potential of Botswana. So, while the environmental aspect of sustainable development is maximised, the economic potential for the country appears to be diminished and the social sustainability is not being addressed. In the African context, and as an example of a developing nation, the view presented by Magole and Magole(2011) is that the regulation of enclave tourism, while providing control for the sustainability of the environment, does not address social or economic sustainability for the people of Botswana. 
Antarctica: Hall and Saarinen (2010) note that while tourism activities in the polar regions is relatively new, and is regarded as having high potential for socio-economic development, the concern is for polar environments, especially in combination with the impact of climate change (p.448). They note that in the polar regions, “...political and economic change appear to be going hand-in-hand with environmental and social change" (p.448). The attention being paid to polar regions by the scientific community in relation to climate change as well as interest in energy resources in the Arctic, have raised concerns by regulatory bodies such as the Arctic and Nordic Councils and member governments, particularly in relation to the indigenous peoples (p.449). This study has documented the visitor statistics, noting that numbers especially in the Arctic region are already substantial. The potential impact of a growing tourism industry in polar regions, at the same time as the effects of climate change are receiving significant focus, will likely determine the political and tourism industry view on the regulatory oversight issues going forward, in a way that is most pertinent for this context.

Australia-Oceana: An example of an expedition cruise location in Australia's far north known as the Kimberley, provides a study of close detail of visitor behavior and tour guide management and related issues. This case study includes a discussion of the need for incorporation of traditional land owners in sustainable strategic development planning. Scherrer, Smith and Dowling (2011) provide examples of inconsistency in operator training and education, resulting in avoidable risks to visitor safety, care of the environment and cultural sites and artifacts. Their recommendations are based around the provision of 'guidelines' rather than regulations, and hinge upon the preparation and on-going professional development of tour operators, including engagement with traditional owners, and better structured preparation of visitor groups (pp.12211222). These suggestions for improvement are provided as a greater imperative than ever, based on the rapid increase in “...number and size of vessels..." (p1218) and anecdotal evidence of impact of greater visitor numbers such as “...trail formation and deterioration, presence of litter, damage to burial sites, vandalism of natural, cultural and historic assets and physical deterioration of rock art” (p.1218).

Japan, Eurasia: Regulation pertaining to ecotourism in Japan, through the Ecotourism Promotion Law (2007), and related policies, requires the employment of tour guides. Yamada (2011) provides background literature on the value that the practice of 'interpretation' can have on sustaining the environment where tourism is promoted, when trained tour guides provide an interpretive experience to tourists. Environmental interpretation has a long history in Japan. Building upon two decades of 'volunteer instructor program' (Yamada, 2011, p142), the Government “...introduced a nature instructor program in parks...” in 1974. This has provided a model for a range of private providers in the ecotourism industry, servicing parks and protected environmental areas throughout Japan since that time. Yamada cites the aims of the Tbilisi Declaration (UNESCO, 1977), for environmental education as: awareness, knowledge, attitudes, skills and participation and proposes that for ecotourism the tour guides have the potential to maximise the achievement of these aims through interpretive guiding. The mandatory provision of tour guides in Japan's ecotourism market, offers the opportunity to build greater capacity through training and possibly accreditation, to influence tourists through a high quality interpretive experience.

Caribbean, Americas: Klak (2009) cites Wall (1997) claiming that “...sustainable ecotourism is simultaneously economically viable, positive for the host and visitor community, and contributes to environmental conservation...”. Klak focuses on the Caribbean region and seeks to reconceptualise sustainable ecotourism in the context of “...small-scale farming, organic agriculture, local artisanry, local control, and broad-based community involvement in local 
alternative tourism...” (Klak, 2009, p. 1041). He proposes a conceptualisation that integrates the key elements of ecotourism, Community-Historical-Organic-Indigenous-Cultural-Ecological tourism, or by the acronym 'CHOICE' tourism (Klak 2009, p.1046, but goes on to suggest that a dichotomy that exists in the literature between mass and alternative tourisms, is superficial and that "...mass tourism needs to learn how to operate more sustainably, and alternative tourism needs to learn how to better market its product, reach customers, and generate earnings...(Klak, 2009 , p. 1045. He is concerned about the promotion of ecotourism development in the region, "...when it is imposed from the top down and prioritizes economic growth to the neglect of community and ecology” (Klak, 2009, p. 1049). He cites large scale complexes in Costa Rica, Central America by way of example, involving displacement of local people in favour of opening up tourist access to the prime natural environment and the imperative of Governments to manage foreign debt and other dependencies in the short term.

\section{Summary}

These cases provide an exploratory reflection on the three positional issues of focus that emerge from the current literature, namely-

1) tourism development and nature conservation are by definition, in conflict

2) there can be sustainable tourism and economic development

3) there can be a state of 'symbiosis' between sustainable ecotourism and social and economic development.

The five cases highlight the mixes of emphasis in the interplay between the three major forces at work in the ecotourism industry- ecological, social and economic, in different countries. The Botswana, African case (Magole and Magole, 2011) provides one view of ecotourism development in a developing country. Interestingly, foreign investment in tourism in Botswana, segregates the pristine, natural areas for tourists, but does not offer the country wider economic development nor a socially sustainable model. Lack of either effective self-regulation of the industry or government regulation compounds these impacts. Further research is needed into how these factors interact in other African countries to provide deeper appreciation of points of like concern and the extent of differences, if any, in either the impact of these forces, or practices on their sustainable management.

In Klak's (2009) conceptualisation based on his work in the Caribbean, he is concerned that the governments' economic imperatives are likewise at the cost of the potential for social improvements and inclusion of the community and impact ecologically. While the social imperative can be conceptualised in his CHOICE model (Community-Historical-OrganicIndigenous- Cultural-Ecological tourism), a longer term government view is need for any progress to be made. He posits that the dimensions of "ecological integrity, economic viability, and social justice" be given equal priority for sustainability to be achieved (p. 1040). The Caribbean region itself, has great diversity within and between countries. The totality of the Americas is far more complex again.

Somewhat more optimistically, Scherrer, Smith and Dowling (2011) consider the ecotourism site of the Kimberley in Australia's far north west. Borrowing from Klak's (2009) model, the emphasis has been on provision of the eco experience for the tourists, at the expense of all the elements in the CHOICE model. They propose that guidelines for the training of tour operators, especially in respect to engagement with traditional owners of the land, is essential if current levels of impact on cultural and historic sites and art works as well as the natural environment are to be stemmed. Other very diverse regions of Australia face different challenges needing focus on sustainability.

In Japan, Yamada (2011) explains that regulation for some decades now, has led to a more comprehensive environmental education foundation underpinning ecotourism, through the mandatory provision of tour guides and the practice of training them in interpretive tourism 
experience. Aspects such as awareness, knowledge, attitudes, skills and participation, derived from the Tbilisi Declaration (UNESCO, 1977), provide a sound basis for wider regulatory initiatives under consideration for Japan. Other countries in Eurasia and elsewhere could benefit from consideration of these initiatives.

Under close scrutiny by the scientific community already, because of the impact of climate change, ecotourism in Antarctica provides a case, where all the critical factors, ecological, social and economic, are receiving close attention. However, Hall and Saarinen (2010) explain that substantial numbers of visitors are becoming of greater to concern to regulatory bodies and particularly in relation to impact on indigenous peoples (p.448).

These cases provide a current reflection on how ecotourism is being situated in the sociocultural, environmental and economic landscapes worldwide. The interplay of factors are variable and dependent upon the quality and effectiveness of focus of political leadership in situ. They do however expose the more fundamental issues of humanity and sustainability, that fail to be addressed more widely, not only in relation to ecotourism.

The contribution of this exploratory research using ecotourism cases located in different countries within diverse regions, has been to exemplify the complexity of the interplay of factors in different scenarios. Urgent further research effort is needed at close quarters to the communities and locations threatened, to better understand the potential for equal balancing of the priorities of the economic, social and environmental features and benefits that appear to be possible from ecotourism. Though generalisable outcomes are unlikely, principles that emerge may at least form a contextual framework within which ecotourism can aspire to work within. Further identification, collation and dissemination of best practices that can demonstrate a more balanced framework is essential. However, awareness of competing perspectives at work within single countries, makes the concept of greater regional cohesion on the issues for sustainable tourism, a challenge of great magnitude and historical significance. 


\section{REFERENCES}

Ayuso, Silvia. Comparing Voluntary Policy Instruments for Sustainable Tourism: The Experience of the Spanish Hotel Sector, Journal of Sustainable Tourism, 15(2), 2007, 144-159.

Bramwell, Bill. Selecting policy instruments for sustainable tourism, In W.F. Theobald (Ed), Global Tourism, (2 ${ }^{\text {nd }}$ edition, 1998, pp.361-379). Oxford, UK.: Butterworth-Heinemann.

Bramwell, Bill and Lane, Bernard. (Editorial) Sustainable tourism and the evolving roles of government planning, Journal of Sustainable Tourism, 18(1) January 2010, 1-5.

Budowski, Gerardo. Tourism and Environmental Conservation: Conflict, Coexistence, or Symbiosis? Environmental Conservation, 3(1) Spring, 1976, 27-31.

Duffy, Rosaleen. The Politics of Ecotourism and the Developing World, Journal of ecotourism, 5, (1\&2), 2006, 1-6.

Freeman, R. and Evan, W.M. Corporate governance: A stakeholder interpretation, Journal of Behavioral Economics, 19, 1990, 337-359.

Garnaut, R. Climate Change Review-Emissions Trading Scheme Report, Commonwealth, State and Territory Governments of Australia March, 2008.

Hall, C. Michael and Saarinen, Jarkko. Polar Tourism: Definitions and Dimensions, Scandinavian Journal of Hospitality and Tourism, 10(4), 2011, 448-467.

Henderson Joan C.Tourism in Dubai: Overcoming Barriers to Destination Development, International Journal of Tourism Research, 8, (2006), 87-99.

Hunter, C. and Green, H. Tourism and the environment: A Sustainable Relationship? 1995, London: Routledge.

Magole, Lefatshe I. and Magole, Lapologang. Revisiting Botswana’s High-Value, Low-Volume Tourism, Tourism Analysis, 16(2), 2011, 203-210).

Moeller, Teresa, Dolnicar, Sara and Leisch, Friedrich. The Sustainability-profitability trade-off in tourism: can it be overcome? Journal of Sustainable Tourism, 19(2), March, 2011, 155169.

Parsons, E.C.M. and Woods-Ballard, A. Acceptance of Volunteer Whalewatching Codes of Conduct in West Scotland: The Effectiveness of Governmental Versus Industry-led Guidelines, Current Issues in Tourism, 6(2), 2003, 172-182).

Romeril, Michael. Tourism and the environment-towards a symbiotic relationship, International Journal of Environmental Studies, 25, 1985, 215-218.

Scherrer, Pascal Smith, Amanda J. and Dowling, Ross K. Visitor management practices and operational sustainability: Expedition cruises in the Kimberley, Australia, Tourism Management, 32, 2011, 1218-1222.

Williams, A. and Montanari, A. Sustainability and self-regulation: Critical perspectives, Tourism Geographiesi, 1(1) 1999, 26-40.

Yamada, Naoko. Why Tour Guiding is Important for Ecotourism: Enhancing Guiding Quality with the Ecotourism Promotion Policy in Japan, Asia Pacific Journal of Tourism Research, 16(2), 2011, 139-152.

\section{ABOUT THE AUTHORS}

Professor Valerie Clulow: Professor Clulow is Deputy Pro Vice Chancellor (Learning and Teaching) in the College of Business, RMIT University, Australia. She has researched and published internationally in areas related to stakeholders and resource-based view, services industries and higher education. Before moving into academe she worked as a senior management development manager in the retail industry in Australia and as a private consultant. She has supervised $\mathrm{PhD}$ and Masters research studies in business strategy, in areas such as retailing, utilities provision, community banking, call centres and business start-ups. 
Dr Gabrielle Walters: Dr Walters is a lecturer in Tourism at the University of Queensland. Her research interests include tourism marketing, disaster recovery and destination image management and her publication portfolio includes a number of internationally acclaimed Tourism Research Journals and marketing handbooks specific to these areas. Prior to her academic career, Gabrielle worked for sixteen years in the tourism and hospitality industry. 